\title{
Model Penanaman dan Frekuensi Aplikasi Bio-Insektisida Sebagai Upaya Pengendalian Hama Terhadap Pertumbuhan dan Hasil Padi Sawah (Oryza sativa, L.)
}

\author{
Nikolas $\mathrm{Nik}^{\mathrm{a}}$ \\ ${ }^{a}$ Fakultas Pertanian, Universitas Timor, Kefamenanu, TTU - NTT, 85613, Indonesia, email: mariaseoteme@yahoo.co.id
}

\section{Article Info}

Article history:

Received 10 September 2015

Received in revised form 12 Oktober 2015

Accepted 15 Novemberr 2015

Keywords:

Model Penanaman

Bio Insektisida

Padi Sawah

\begin{abstract}
Abstrak
Penelitian ini bertujuan untuk mendapatkan aplikasi bioinsektisida dan sistem tanam yang tepat terhadap pertumbuhan dan hasil padi sawah yang maksimal, dilaksanakan di lahan sawah Benkoko, Desa Letmafo, Kecamatan Insana Tengah, Kabupaten TTU pada bulan Februari sampai Juni 2014. Percobaan menggunakan Rancangan Acak Kelompok (RAK) 2 x 3 yang diulang tiga kali. Faktor pertama adalah frekuensi aplikasi bioinsektisida yang terdiri dari satu kali aplikasi dan dua kali aplikasi bioinsektisida. Faktor kedua adalah sistem tanam yang terdiri dari sistem legowo 2:1, sistem legowo 3:1, sistem legowo 4:1 dan sistem tegel $20 \times 20 \mathrm{~cm}$. Hasil penelitian menunjukan bahwa perlakuan cara tanam jajar legowo lebih cenderung meningkatkan bobot gabah kering panen dan mengurangi adanya serangan hama pada tanaman padi sawah. Penggunaan bioinsektisida 2 kali aplikasi cenderung meningkatkan hasil namun secara ekonomis 1 kali aplikasi bioinsektisida sudah cukup untuk mengurangi populasi hama. (02016 dipubikasikan oleh Savana Cendana.
\end{abstract}

\section{Pendahuluan}

Tanaman padi merupakan tanaman yang dijadikan sebagai bahan makanan pokok sehingga permintaan terus meningkat dari tahun-ke tahun. Produksi padi di Indonesia mengalami penurunan, hal ini disebabkan oleh beberapa faktor dan salah satu diantaranya adalah kerusakan yang disebabkan oleh hama dan cara pengaturan tanam. Untuk itu dibutuhkan teknologi cara penanaman padi yang lebih inovatif yang dapat menambah produktivitas padi sekaligus mengendalikan organisme pengganggu tanaman padi. Penerapan sistem tanam yang tepat dan pemberian bioinsektisida dapat meningkatkan produksi

Pengembangan sistem penanaman diharapkan merupakan salah satu teknologi alternatif pilihan sebagai inovasi teknologi partisipatif dan spesifik lokasi yang dikenal dengan sebutan sistem Pengelolaan Tanaman Terpadu (PTT) yang berkembang yang disesuaikan dengan keinginan petani setempat (Hasanudin, 2004). PTT merupakan suatu pendekatan yang mempertimbangkan keserasian dan sinergisme antara komponen teknologi budidaya dengan sumberdaya lingkungan setempat. Paket teknologi yang disiapkan bersifat spesifik lokasi, yang dapat menghasilkan sinergisme dan efisiensi tinggi, sebagai wahana pengelolaan tanaman dan sumberdaya spesifik lokasi.

Sistem tanam legowo 4:1, 3:1, dan 2:1 merupakan alternatif komponen teknologi dalam padi sawah irigasi. Pemilihan komponen teknologi PTT didasarkan pada identifikasi wilayah dan permasalahan usahatani padi dapat diharapkan sebagai peluang untuk mengatasi masalah produktivitas padi.

Sistem tanam legowo adalah sistem tanam berselang-seling antara dua atau lebih baris tanaman padi dan satu baris kosong. Baris tanaman (dua atau lebih) dan baris kosongnya (setengah lebar di kanan dan di kirinya) disebut satu unit legowo. Bila terdapat dua baris tanaman per unit legowo, maka disebut legowo $2: 1$, kalau tiga baris tanaman per unit legowo disebut 3:1 dan seterusnya (Abdurrachman, 2004).

Cara tanam legowo 2:1 memberikan hasil gabah tertinggi sebesar 6,25 t/ha dan hasil gabah terendah dengan cara tanam tegel $20 \times 20 \mathrm{~cm}$ sebesar 5,52 t/ha (BPTP Sumsel, 2006). Cara Tanam Tegel merupakan sistem tanam yang biasa digunakan oleh masyarakat petani pada umumnya yaitu sistem tanam tanpa memperhatikan jarak maupun baris secara teratur.

Dengan diterapkannya cara tanam sistem legowo yang menambah kemungkinan barisan tanaman untuk mengalami efek tanaman pinggir, sinar matahari dapat dimanfaatkan lebih banyak untuk proses fotosintesis. Pada lahan yang lebih terbuka karena adanya lorong pada baris tanaman, serangan hama, khususnya tikus, dapat ditekan karena tikus tidak suka tinggal di dalamnya dan dengan terciptanya kelembaban lebih rendah, perkembangan penyakit dapat juga ditekan. Tidak hanya itu, pemupukan dan pengendalian organisme pengganggu tanaman menjadi lebih mudah dilakukan di dalam lorong-lorong.

Selain manfaat sistem tanam jajar legowo juga punya kelemahan antara lain: a) Membutuhkan tenaga tanam yang lebih banyak dan waktu tanam yang lebih lama pula; b) Membutuhkan benih yang lebih banyak dengan semakin banyaknya populasi; c) Biasanya pada legowonya akan lebih banyak ditumbuhi rumput.

Selain sistem tanam dalam budidaya tanaman padi selalu dihadapi dengan masalah hama yang dapat menyebabkan produksi menurun dan mutunya kurang baik. Beberapa jenis hama yang menyerang tanaman padi antara lain: a) Hama penggerek batang padi merupakan hama yang sangat penting pada padi dan sering menimbulkan kerusakan dan menurunkan hasil panen secara nyata. Kerusakan dapat dilihat dari adanya negengat dipertanaman dan larva di dalam batang. Mekanisme kerusakan disebabkan larva merusak sistem pembuluh tanaman di dalam batang. Penggerek batang padi menyerang tanaman padi saat padi pada semua fase pertumbuhan tanaman, yang menimbulkan gejala sundep pada fase pertumbuhan vegetatif dan beluk (malai hampa pada fase pertumbuhan generatif). Penggerek batang dibedakan menjadi tiga yakni penggerek batang padi kuning (Schirphopaga incertulas Walker), penggerek batang padi putih (Schirphopaga inotata Walker) dan penggerek batang padi bergaris (Chilo suppressalis Walker); b) Wereng coklat sebelumnyatermasuk hama sekunder dan menjadihama yang sangat penting akibat penyemprotan pestisida yang tidak tepatpada awal pertumbuhan tanaman sehingga membunuh musuh alami.
Pertanaman yang dipupuk dengan nitrogen yang tinggi dengan jarak tanam yang rapat merupakan kondisi yang sangat disukai wereng coklat. Stadia tanaman yang rentan terhadap serangan wereng coklat dari persemaian sampai fase matang susu. Gejala kerusakan yang ditimbulkannya adalah tanaman menguning dan cepat sekali mengering. Umumnya gejala terlihat mengumpul pada satu titik lokasi melingkar disebut hopperburn (Dirjen Perlintan, 2007). Kalau populasi sudah tinggi sekali dapat menyebabkan matinya tanaman dalam satu hamparan,keadaan ini disebut dengan puso. Wereng coklat juga dapat menularkan virus (Suharto, 2007); c) Walang sangit (Laptocorisa oratorius (Fabricius) merupakan hama yang merusak bulir padi pada fase masak susu. Serangga dewasa apabila diganggu akan mempertahankan diri dengan mengeluarkan bau, yang juga bisa dapat menarik walang sangit lain dari spesies yang sama. Fase pertumbuhan tanaman padi yang rentan terhadap serangan walang sangit adalah saat keluarnya malai sampai matang. Kerusakan yang ditimbulkan menyebabkan beras berubah warna, mengapur serta banyak hampa (Dirjen Perlintan, 2007).

Rendahnya produksi padi disebabkan karena kurangnya pengetahuan petani tentang penggunaan bioinsektisida dalam mengendalikan hama padi. Bioinsektisida adalah zat racun yang berasal dari tumbuh-tumbuhan atau mikroorganisme lainnya yang dapat dimanfaatkan untuk membunuh hama atau bersifat sebagai penyebab penyakit untuk hama atau jasad renik lainnya. Bioinsektisida ini merupakan pestisida yang bersifat ramah lingkungan. Pestisida ini muncul karena adanya keraguan dari penggunaan pestisida kimia sehingga orang mulai mencari pengendalian alternatif lain. Cara pengendalian alternatif ini diharapkan dapat mengatasi atau setidaknya mengurangi permasalahan penggunaan pestisida kimia yang dapat diterapkan dengan mudah. Berkaitan dengan persyaratan tersebut, pemanfaatan tumbuhan berkhasiat sebagai salah satu alternatif untuk pengendalian hama. Informasi yang ada menunjukkan bahwa penggunaan bioinsektisida memiliki beberapa keunggulan, antara lain mudah terurai di lingkungan, efektif terhadap hama sasaran, cukup aman bagi musuh alami dan bersifat ramah lingkungan. Kelebihan tersebut sejalan dengan konsep PHT yang sangat bermanfaat bagi masyarakat pengguna insektisida dan tidak menimbulkan dampak negatif bagi organisme lain.

Agensia hayati yang berpotensi untuk dikembangkan sebagai sarana pengendalian hama antara lain cendawan patogenik Metarhizium anisopliae Wibowo (2006) dalam penelitiannya melaporkan bahwa virulensi Metarhizium anisopliae terhadap belalang kembara adalah $11,8 \%$ setiap hari hingga menyebabkan kematian belalang setelah 8,45 hari. Metarhizium anisopliae merupakan cendawan yang paling penting dalam pengendalian hama. Ada beberapa strain cendawan yang diketahui dan Metarhizium anisopliae merupakan salah satu pendekatan yang digunakan untuk pengendalian belalang. Di Australia umumnya pengendalian belalang menggunakan Metarhizium anisopliae var acridum (F1 985) (Milner 1997). Bio-insektisida yang beris konidia Metarhizium anisopliae var acridum (Deuteromycotina: Hyphomycetes) yang diproduksi untuk pengendalian populasi belalang kembara. Pestisida ini bersifat ramah lingkungan. Hasil uji coba di Australia, Cina dan Timor Leste cukup efektif dalam pengendalian hama belalang kembara (Loung dan Hunter, 2005). Selanjutnya hasil penelitian Nik (2009), bio-insektisida cendawan Metarhizium anisopliae yang diformulasikan dengan minyak nabati akan lebih efektif dan efisien untuk mengendalikan hama belalang kembara dan mengalami kematian setelah 4-14 hari setelah aplikasi serta pada bagian tubuh dan abdomennya akan tumbuh jamur yang berwarna putih kehijauan.

Penelitian ini bertujuan untuk mendapatkan aplikasi bioinsektisida dan sistem tanam yang tepat terhadap pertumbuhan dan hasil padi sawah yang maksimal.

\section{Metode}

2.1 Tempat dan Waktu

Penelitian ini telah dilaksanakan di lahan sawah Benkoko, Desa Letmafo, Kecamatan Insana Tengah, Kabupaten TTU. Waktu pelaksanaan dilaksanakan pada bulan Februari sampai Juni 2014. 


\subsection{Rancangan Percobaan}

Dalam percobaan ini menggunakan Rancangan Acak Kelompok (RAK) 2 x 3 yang diulang tiga kali. Faktor pertama adalah frekuensi aplikasi bioinsektisida yang terdiri dari satu kali aplikasi $\left(\mathrm{a}_{1}\right)$ dan dua kali aplikasi bioinsektisida $\left(\mathrm{a}_{2}\right)$. Faktor kedua adalah sistem tanam yang terdiri dari sistem legowo 2:1 $\left(l_{1}\right)$, sistem legowo 3:1 ( $\mathrm{l}_{2}$ ), sistem legowo 4:1 (L3) dan sistem tegel $20 \mathrm{x} 20 \mathrm{~cm}\left(\mathrm{l}_{4}\right)$. Jumlah petak perlakuan sebanyak 24 unit percobaan.

\subsection{Pelaksanaan Penelitian}

a. Persiapan Lahan

Lahan dibersihkan dari gulma-gulma dan sisa-sisa tanaman yang ada dengan menggunakan sabit atau cangkul secara manual.

b. Pengolahan Tanah

Tanah dibajak pada kondisi kapasitas lapang/tidak terlalu basah dengan menggunakan hand traktor sampai gembur dan diratakan

c. Persiapan Pembibitan

Benih yang digunakan adalah benih padi lokal merah. Sebelum benih disemaikan lebih dahulu dilakukan sortasi benih, selanjutnya dijemur 3-5 hari serta direndam selama 24 jam kemudian dikeringangin selama 48 jam. Benih ditabur pada petak persemaian dan diberi pupuk kandang serta abu sekam untuk memudahkan saat pencabutan anakan.

d. Pembuatan Petak Penanaman

Petak penanaman dikerjakan setelah pengolahan tanah dengan ukuran petak $1 \mathrm{~m} \times 2 \mathrm{~m}$ yang berjumlah sebanyak 24 unit percobaan.

e. Penanaman

Penanaman bibit yang berumur 21 HST dengan sistem tanam tegel $20 \times 20$ $\mathrm{cm}$ dan sistem tanam legowo 2:1 jarak tanam $20 \times 10 \mathrm{~cm}$, sistem legowo 3:1 dan sistem legowo 4:1dengan lebar lorong $40 \mathrm{~cm}$, dan jumlah bibit 2 anakan per lubang.

\section{f. Pemupukan}

Pemupukan menggunakan pupuk organik dengan takaran 5 t/ha diberikan tujuh hari sebelum tanam.

g. Pengairan

Pengairan dilakukan setinggi $\pm 15 \mathrm{~cm}$, dan tenggang waktu pemberian disesuaikan dengan kondisi lahan.

h. Penyiangan Gulma

Untuk mencegah pertumbuhan awal gulma maka sehari sebelum menanam dapat dilakukan pemberian herbisida pratumbuh (logran). Penyiangan gulma selanjutnya dapat dilakukan dengan cara mencabut gulma.

i. Aplikasi Bioinsektisida

Pengendalian Organisme Pengganggu Tanaman/Hama dilakukan sesuai perlakuan yaitu 1 kali aplikasi bioinsektisida pada saat tanaman padi berumur 45 HST dan 2 kali aplikasi yakni pada 45 HST dan 65 HST. Dosis yang diberikan adalah $250 \mathrm{ml}$ Green Guard (bioinsektisida yang berisi konidium Metarizium anisopliae, L.) yang diformulasikan dengan minyak kelapa $1250 \mathrm{ml}$ yang dapat disemprotkan untuk luasan 1 ha. Waktu aplikasi di lakukan pada pagi hari dengan menggunakan handsprayer.

j. Panen

Panen padi dilakukan sekitar umur 105 hari yaitu pada saat padi sudah menguning $90 \%$, pemanenan dilakukan dengan memotong rumpun menggunakan sabit kemudian dirontok secara manual.

\subsection{Parameter Pengamatan}

a. Kerusakan anakan per rumpun pada setiap tanaman sampel dihitung dengan rumus:

$$
\text { Kerusakan }=\frac{\text { Jumlah Anakan Rusak }}{\text { Total Anakan }} \times 100 \%
$$

b. Kerusakan biji hampa per rumpun pada setiap tanaman sampel dihitung dengan menggunakan rumus:

$$
\text { Kerusakan Biji }=\frac{\text { Jumlah Biji Rusak }}{\text { Total Biji }} \times 100 \%
$$

c. Berat kering biji bernas/tanaman sampel dilakukan dengan cara mengumpulkan semua biji padi pada setiap rumpun tanaman sampel kemudian dioven dan ditimbang sampai mencapai berat konstanta.

d. Berat kering biji bernas/petak dilakukan dengan cara mengumpulkan semua biji padi pada pada petak perlakukan kemudian dijemur dibawah sinar matahari dan selanjutnya ditimbang sampai mencapai berat konstanta.

e. Berat kering berangkasan/petak dilakukan dengan cara dijemur di bawah sinar matahari sampai mencapai berat konstanta.

\subsection{Analisis Data}

Data hasil pengamatan dianalisis dengan menggunakan sidik ragam (Anova), Rancangan Acak Kelompok (RAK) untuk mengatahui ada tidaknya interaksi antara faktor perlakuan. Selanjutnya untuk mendapatkan beda nyata antara rerata perlakuan akan diuji dengan Duncan Multiple Test (DMRT) dengan tingkat signifikan 5\%.

\section{Hasil dan Pembahasan}

3.1 Kerusakan Anakan Per Rumpun

Hasil analisis sidik ragam menunjukan bahwa tidak terjadi interaksi antar faktor, demikian juga halnya dengan antar perlakuan tidak ada perbedaan yang nyata namun ada kecenderungan bahwa pada perlakuan 1 kali aplikasi bioinsektisida jumlah anakan yang rusak yang diakibatkan oleh adanya serangan hama cenderung lebih banyak dibanding dengan 2 kali aplikasi. Hal ini diduga bahwa pada perlakuan yang disemprot 1 kali bioinsektisidanya belum cukup efektif untuk mematikan hama dan bioinsektisida tersebut mudah cepat terurai di alam. Hal tersebut didukung oleh (Oudejans, 1991) yang mengatakan bahwa cepatnya penguraian senyawa aktif merupakan salah satu pertimbangan dalam pemilihan dan pemakaian insektisida. Selanjutnya hasil penelitian (Saputra dan Prijono, 2003) mengatakan bahwa sifat-sifat senyawa insektisida botani selain efektif pada hama sasaran, rendemen yang tinggi, aman terhadap organisme bukan sasaran, spektrum bioaktivitas yang tinggi dapat merupakan salah satu pertimbangan yang penting dalam menentukan dapat tidaknya suatu bahan dikembangkan menjadi sumber insektisida botani baru. Pada perlakuan 2 kali aplikasi bioinsektisida dapat mengurangi populasi hama sehingga kerusakan tanaman akan berkurang. Selanjutnya dikatakan bahwa pengelolaan hama yang dilakukan dalam konteks lingkungan terkait dan dinamika populasi spesies hama, memanfaatkan semua teknik dan metode pengendalian yang sesuai dan sekompatibel mungkin, serta mempertahankan populasi hama pada aras dibawah aras ambang ekonomi yang dapat mengakibatkan kerusakan atau kehilangan hasil.

\begin{tabular}{|c|c|c|c|c|c|}
\hline \multirow{2}{*}{$\begin{array}{c}\text { Frekuensi } \\
\text { Aplikasi }\end{array}$} & \multicolumn{3}{|c|}{ Jajar Legowo } & \multirow{2}{*}{ Tegel } & \multirow{2}{*}{ Rerata } \\
\hline & $2: 1$ & $3: 1$ & $4: 1$ & & \\
\hline 1 Kali & 8,421 & 8,533 & 9,158 & 5,775 & $7,971 \mathrm{a}$ \\
\hline 2 Kali & 1,944 & 1,944 & 2,458 & 1,478 & $4,206 \mathrm{a}$ \\
\hline Rerata & $5,182 \mathrm{a}$ & $5,238 \mathrm{a}$ & $5,808 \mathrm{a}$ & $8,126 \mathrm{a}$ & $(-)$ \\
\hline Keterangan & $\begin{array}{l}\text { Ang } \\
\text { berb }\end{array}$ & & pada bar & kolon & \\
\hline
\end{tabular}

Tabel 1. Kerusakan Anakan Per Rumpun (\%)

\subsection{Kerusakan Biji Gabah Kering Per Rumpun}

Hasil analisis sidik ragam menunjukan bahwa tidak terjadi interaksi antar faktor. Model tanam dengan perlakuan tegel $(20 \mathrm{~cm}$ x $20 \mathrm{~cm})$ kerusakan biji gabah nyata lebih tinggi. Hal ini diduga bahwa terjadinya kompetisi antar tanaman yang tinggi dalam hal memperoleh unsur hara sehingga meningkatkan jumlah biji rusak lebih tinggi. Berdasarkan hasil penelitian bahwa frekuensi aplikasi bioinsektisida tidak terjadi perbedaan yang nyata antar perlakuan, karena diduga bahwa bioinsektisida yang diberikan belum dilakukan secara tepat waktunya sehingga hama lebih awal menyerang tanaman sehingga menimbulkan banyak biji yang hampa. Hal yang sama dikemukakan oleh Khan et . al (1991) pengendalian hama penggerek batang sulit dikendalikan dengan insektisida karena telur yang menetas jadi ulat sebelum menyerang tunas hanya mempunyai waktu singkat untuk diaplikasi insektisida secara efektif.

Tabel 2. Kerusakan Biji Gabah Per Rumpun (\%)

\begin{tabular}{cccccc}
\hline Frekuensi & \multicolumn{3}{c}{ Jajar Legowo } & \multirow{2}{*}{ Tegel } & \multirow{2}{*}{ Rerata } \\
\cline { 2 - 5 } Aplikasi & $2: 1$ & $3: 1$ & $4: 1$ & & \\
\hline 1 Kali & 16,336 & 14,296 & 13,081 & 36,771 & $20,121 \mathrm{a}$ \\
2 Kali & 21,928 & 13,366 & 22,403 & 22,790 & $20,122 \mathrm{a}$ \\
\hline Rerata & $19,132 \mathrm{~b}$ & 13,831 a & $17,742 \mathrm{~b}$ & $29,780 \mathrm{c}$ & $(-)$ \\
\hline Keterangan : & $\begin{array}{l}\text { Angka yang diikuti oleh huruf pada baris dan kolom yang sama, tidak } \\
\end{array}$ & berbeda nyata pada uji lanjut DMRT $\alpha$ 5\%. ( - ) : Tidak terjadi interaksi.
\end{tabular}

\subsection{Berat Kering Gabah Biji Per Rumpun}

Hasil analisis sidik ragam menunjukan bahwa tidak terjadi interaksi antar faktor, demikian juga halnya dengan antar perlakuan tidak ada perbedaan yang nyata namun ada kecenderungan bahwa pada perlakuan 2 kali aplikasi bioinsektisida menunjukkan bahwa berat kering gabah cenderung lebih berat dibanding dengan 1 kali aplikasi bioinsektisida. Hal ini disebabkan karena pada perlakuan 2 kali aplikasi bioinsektisida, hama walang sangit kurang merusak biji padi terutama saat masak susu dan hasil pengamatan lapang terlihat bahwa ketika disemprot dengan bioinsektisida walang sangit mengalami gangguan sehingga kemampuan untuk merusak biji menurun. Dengan demikian biji yang tidak terserang akan berpengaruh terhadap berat kering.

\section{Tabel 3. Berat Kering Biji Per Rumpun (g)}

\begin{tabular}{cccccc}
\hline Frekuensi & \multicolumn{3}{c}{ Jajar Legowo } & \multirow{2}{*}{ Tegel } & \multirow{2}{*}{ Rerata } \\
\cline { 2 - 4 } Aplikasi & $2: 1$ & $3: 1$ & $4: 1$ & & \\
\hline 1 Kali & 132,743 & 129,120 & 126,560 & 96,500 & $121,230 \mathrm{a}$ \\
2 Kali & 140,180 & 146,333 & 91,526 & 82,140 & $115.044 \mathrm{a}$ \\
\hline Rerata & 136,461 a & 137,725 a & 109,043 a & 89,320 a & $(-)$ \\
\hline Keterangan : & Angka yang diikuti oleh huruf pada baris dan kolom yang sama, tidak \\
& \multicolumn{1}{c}{ berbeda nyata pada uji lanjut DMRT $\alpha$ 5\%. (- ) : Tidak terjadi interaksi. }
\end{tabular}

\subsection{Berat Kering Gabah Per Petak}

Hasil analisis sidik ragam menunjukan bahwa tidak terjadi interaksi antar faktor, namun ada kecenderungan bahwa pada perlakuan yang diberi pestisida menunjukkan bahwa berat kering gabah cenderung lebih berat dibanding dengan yang tidak diberi pestisida. Pada petak yang diberi perlakuan pestisida hama 
kurang merusak biji terutama saat masak susu. Selain itu juga dipengaruhi oleh tingkat jumlah anakan yakni pada petak yang diberi pestisida kerusakan anakan per rumpun lebih kecil sehingga jumlah anakan yang tidak terserang dapat berpengaruh terhadap berat gabah kering per satuan luas.

Tabel 4. Berat Kering Biji Per Petak (kg)

\begin{tabular}{cccccc}
\hline Frekuensi & \multicolumn{3}{c}{ Jajar Legowo } & \multirow{2}{*}{ Tegel } & \multirow{2}{*}{ Rerata } \\
\cline { 2 - 4 } Aplikasi & $2: 1$ & $3: 1$ & $4: 1$ & & \\
\hline 1 Kali & 1405,523 & 1333,960 & 1187,446 & 1157,600 & $1271,132 \mathrm{a}$ \\
2 Kali & 1629,533 & 1521,390 & 1289,890 & 1679,280 & $1239,774 \mathrm{a}$ \\
\hline Rerata & 1517,528 a & 1427,675 a & 1238,668 a & 1418,440 a & $(-)$ \\
\hline Keterangan : & $\begin{array}{l}\text { Angka yang diikuti oleh huruf pada baris dan kolom yang sama, tidak } \\
\text { berbeda nyata pada uji lanjut DMRT } \alpha \text { 5\%. ( - ) : Tidak terjadi interaksi. }\end{array}$
\end{tabular}

\subsection{Berat Kering Berangkasan}

Hasil analisis sidik ragam menunjukan bahwa terjadi interaksi antar faktor, namun ada kecenderungan bahwa pada perlakuan yang diberi bioinsektisida 1 kali menunjukkan bahwa berat kering berangkasan cenderung lebih berat dibanding dengan 2 kali aplikasi bioinsektisida. Sistem tanam legowo 3:1 diduga populasi tanamannya lebih tinggi sehingga akan cenderung menghasilkan jumlah berangkasan yang lebih banyak dengan berat yang tentunya akan menjadi lebih tinggi jika dibandingkan yang dihasilkan oleh sistem tanam lainnya. Diduga bahwa sistem tanam legowo pada barisan tanaman di bagian pinggir dapat meningkatkan hasil dan relatif lebih aman dari serangan hama tikus.

Tabel 5. Berat Kering Berangkasan Per Petak

\begin{tabular}{cccccc}
\hline Frekuensi & \multicolumn{3}{c}{ Jajar Legowo } & \multirow{2}{*}{ Tegel } & \multirow{2}{*}{ Rerata } \\
\cline { 2 - 4 } Aplikasi & $2: 1$ & $3: 1$ & $4: 1$ & & \\
\hline 1 Kali & $10,332 \mathrm{Aa}$ & $11,040 \mathrm{Aa}$ & $7,753 \mathrm{Aab}$ & $9,679 \mathrm{Aa}$ & 9,701 \\
$2 \mathrm{Kali}$ & $7,546 \mathrm{Bab}$ & $5,645 \mathrm{Ba}$ & $9,213 \mathrm{Ab}$ & $9,703 \mathrm{Ab}$ & 8,026 \\
\hline Rerata & 8,894 & 8,342 & 8,483 & 9,691 & $(+)$ \\
\hline Keterangan : & Angka yang diikuti oleh huruf pada baris dan kolom yang sama, tidak \\
& \multicolumn{2}{c}{ berbeda nyata pada uji lanjut DMRT $\alpha$ 5\%. (+ ) : Terjadi interaksi. }
\end{tabular}

4. Simpulan

a. Perlakuan cara tanam jajar legowo lebih cenderung meningkatkan bobot gabah kering panen dan mengurangi adanya serangan hama pada tanaman padi sawah.

b. Penggunaan bioinsektisida 2 kali aplikasi cenderung meningkatkan hasil namun secara ekonomis 1 kali aplikasi bioinsektisida sudah cukup untuk mengurangi populasi hama.

\section{Daftar Pustaka}

Hasanuddin, A. 2004. Pengelolaan tanaman padi terpadu; suatu strategi pendekatan teknologi spesifik lokasi. Makalah disampaikan pada Pelatihan Pengembangan Varietas Unggul Tipe Baru (VUTB) Fatmawati dan VUB Lainnya 31 Maret-3 April 2004, di Balitpa, Sukamandi.

Khan Z.R, J.A Litsinger, A.T Barrion, F.F.D Villa nueva, N. J Fernandez, L.D. Taylo. 1991. World Bibliography of Rice Stemborers 1794 - 1990. IRRI.ICIPE, $415 \mathrm{hlm}$.

Milner, RJ, 1997. Metharhizium flavoviride ( F1 985) as apromissing mycoinsecticide for Australian acridids. Pp 287 - 300. In: Microbial Control of Grasshopper and Locusts. Goettel MS. Johnson DI. (Eds) Memoir 171 of the Entomological Society of Canada.

Nik, N. 2009. Kajian Aspek Ekologi Belalang Kembara (Locusta migratoria, L) (Orthoptera: Acrididae) dan Aplikasi Bio-Insektisida Dalam Pengendaliaannya Di Kabupaten Timor Tengah Utara dan Belu Propinsi Nusa Tenggara Timur. Thesis Institut Pertanian Bogor.

Oudejans JH, 1991. Agro-Pesticides: properties and functions in integrated crop protection. Bangkok United Nations Economic and social Commision for Asia and The Pacific.

Suharto, 2007. Pengenalan \& Pengendalian Hama Tanaman Pangan. Andi, Yokyakarta.

Saputra, E dan Prijono, D. 2003. Formulasi Insektisida Botani dari Sediaan Kulit Batang Calolphylium soulatri Burn F. Prosiding Seminar Nasional Entomologi Dalam Perubahan Lingkungan dan Sosial, Bogor 5 Oktober 2004.

Wibowo, 2006. Studi Virulensi Cendawan Patagonik Metharhizium anisopliae dan Beauveria bassiana pada Hama Belalang Kembara (Locusta migratoria manilensis Me yen).

Loung Z, Hunter DM, 2005. Laboratory and Field trials of GreenGuard (Metharhizium anisopliae var. Acridum) (Deuteromycotina:Hyphomycetes) against the oriental migratory locust (Locusta migratoria manilensis) (Orthoptera:Acrididae) in China. 